\title{
Hadâmbu sector of Iași cuesta escarpment - recent mass movement processes and deforestation
}

\author{
Mihai Ciprian Mărgărint, Mihai Niculiță, Silviu Doru \\ Department of Geography, Faculty of Geography and Geology \\ Alexandru Ioan Cuza University of Iaşi \\ Iaşi, Romania \\ mihai.niculita@uaic.ro, margarint.ciprian@yahoo.com
}

\section{INTRODUCTION}

The Moldavian Plateau is one of the most representative hilly area and one of the regions most affected by mass movement processes from Romanian. A recent regional historical landslide inventory [1] showed that the general pattern of landslide distribution emphasizes a repetitive model along cuesta scarp slopes. This pattern is related to the lithology and landforms as preconditioning factors. The lithology of the area is dominated by caprocks of limestones, sandstones, and volcanic consolidated tuffs over friable clayey and sandy strata intercalations [1].

The contact between the Central Moldavian Plateau and the Jijia Hills, known as Iaşi cuesta escarpment exhibit the mentioned landform, lithologic and structural pattern, being one of the areas of the Moldavian Plateau where the landslide density is the highest [1]. At the edge of the Central Moldavian Plateau the Upper Bessarabian limestone and sandstone layers known as Repedea Limestone Formation, overlay the Medium Bessarabian clayey and sandy layers known as Cryptomactra Clays Formation [2, 3].

\section{LANDSLIDES FROM HADÂMBU SECTOR}

In the Hadâmbu sector of the Iaşi cuesta escarpment the old landslides were reactivated by recent deforestation and slope cutting for road construction (Figs 1 and 2). This sector illustrates better the effect of land use and anthropic preparatory factors. The landslide reactivations were triggered by heavy rainfalls which overlapped with the snowmelt, and in general happened during March-April interval.

In the last few years, these dense reactivations of old landslides created major dysfunctions for the local communities, despite major investments in road repair.

For the road sector that climb this part of Iaşi Cuesta (between Hadâmbu village and Hadâmbu Monastery DC49), in 2009 around 2 million of RON were invested for the rehabilitation of the damages induced by previous reactivations. Five years later, the reactivation of the old landslide affected again the road after a spring rainy period. The same situation was recorded in March this year a few kilometers to the west in the Voineşti sector of Iaşi cuesta escarpment.

The deforestation along this sector (Figs 3 and 4) happened between 1890 and 1920 .

\section{CONCLUSIONS}

Considering the presented situation we argue that by continuing to invest only in the road infrastructure after landslide induced damages, the history will repeat, especially if future rainy period will emerge. The only chance to provide a long term solution is to study in depth the hydrogeological conditions of the site and to invest in technical drainage infrastructure and reforestation.

\section{ACKNOWLEDGMENT}

We are grateful to Prut-Bârlad Water Administration who provided us with the LIDAR data. We have used the computational facilities given by the infrastructure provided through the POSCCE-O 2.2.1, SMIS-CSNR 13984-901, No. 257/28.09.2010 Project, CERNESIM (L4).

\section{REFERENCES}

[1] M.C. Mărgărint and M. Niculiţă, "Landslide type and pattern in Moldavian Plateau, NE Romania”, in Landform Dynamics and Evolution in Romania, M. Rădoane and A. Vespremeanu-Stroe, Eds., Springer, 2017, pp. 271-304. doi:10.1007/978-3-319-32589-7_12

[2] M Brânzilă, Geologia părţii sudice a Câmpiei Moldovei. Iaşi: Editura Corson, 1999. (in Romanian)

[3] L. Ionesi, B. Ionesi, V. Roşca, A. Lungu, and V. Ionesi, Sarmatianul mediu și superior de pe Platforma Moldovenească. București: Editura Academiei Române, 2005. (in Romanian) 


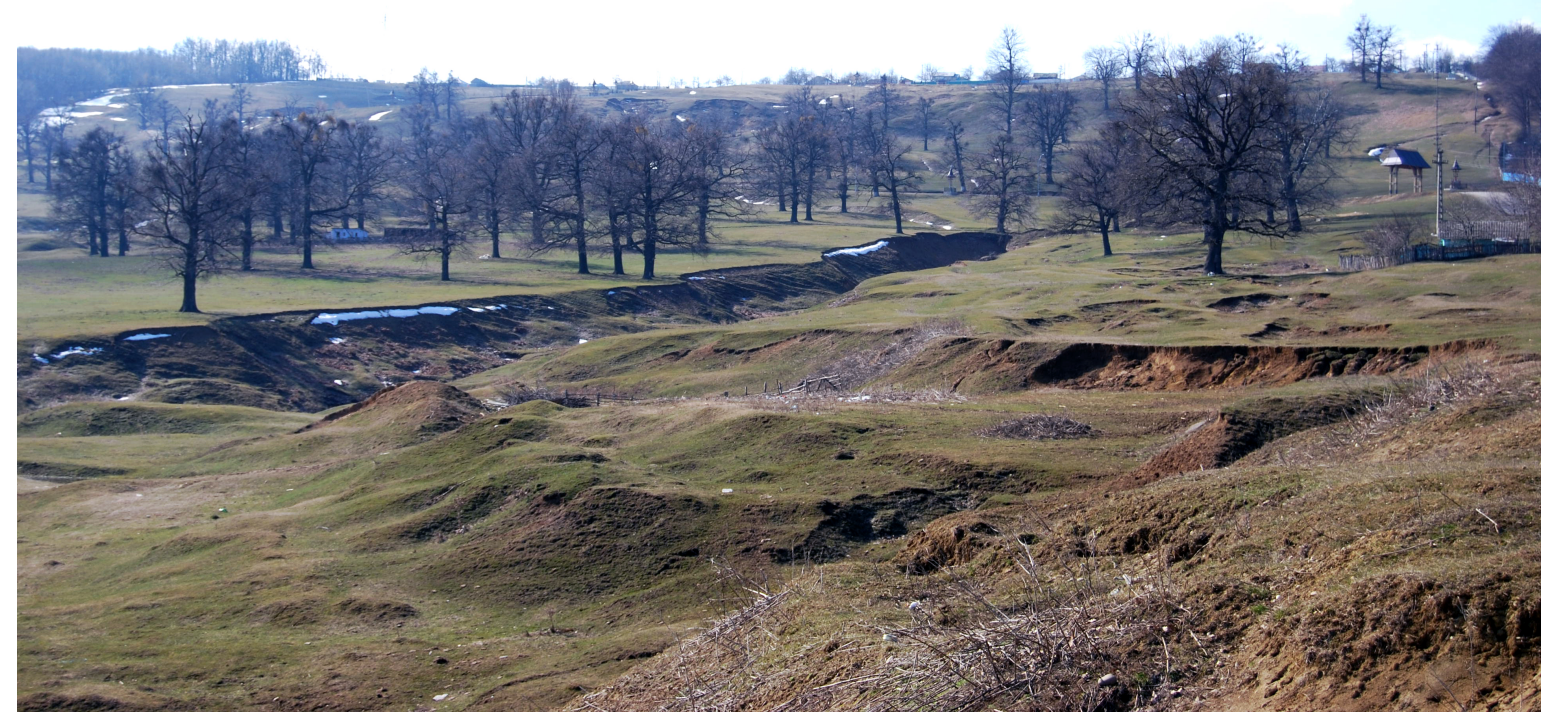

Fig. 1. General view on the deforested slope between Hadâmbu village and Hadâmbu Monastery.

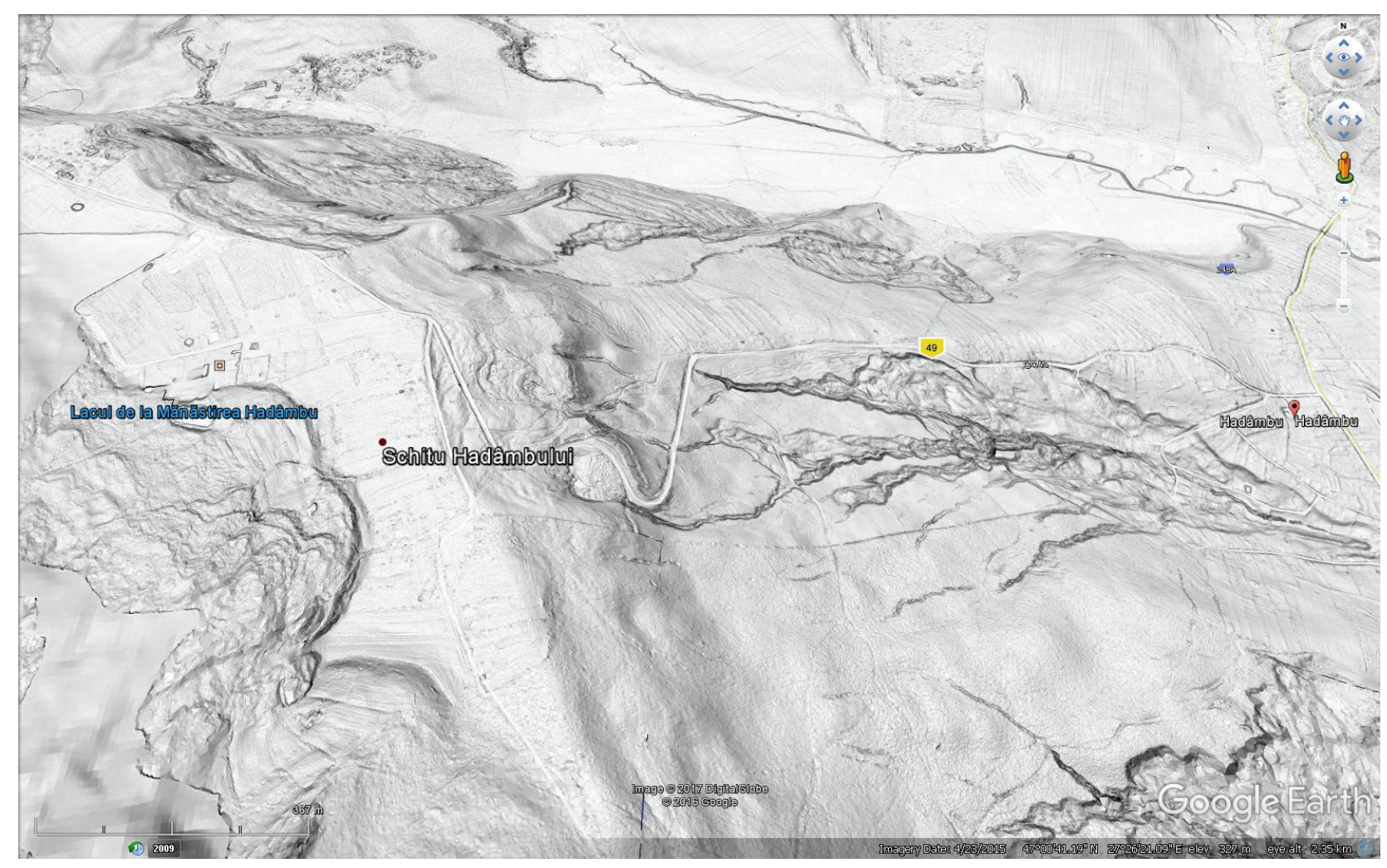

Fig. 2. LiDAR shading image of the slope between Hadâmbu village and Hadâmbu Monastery. 


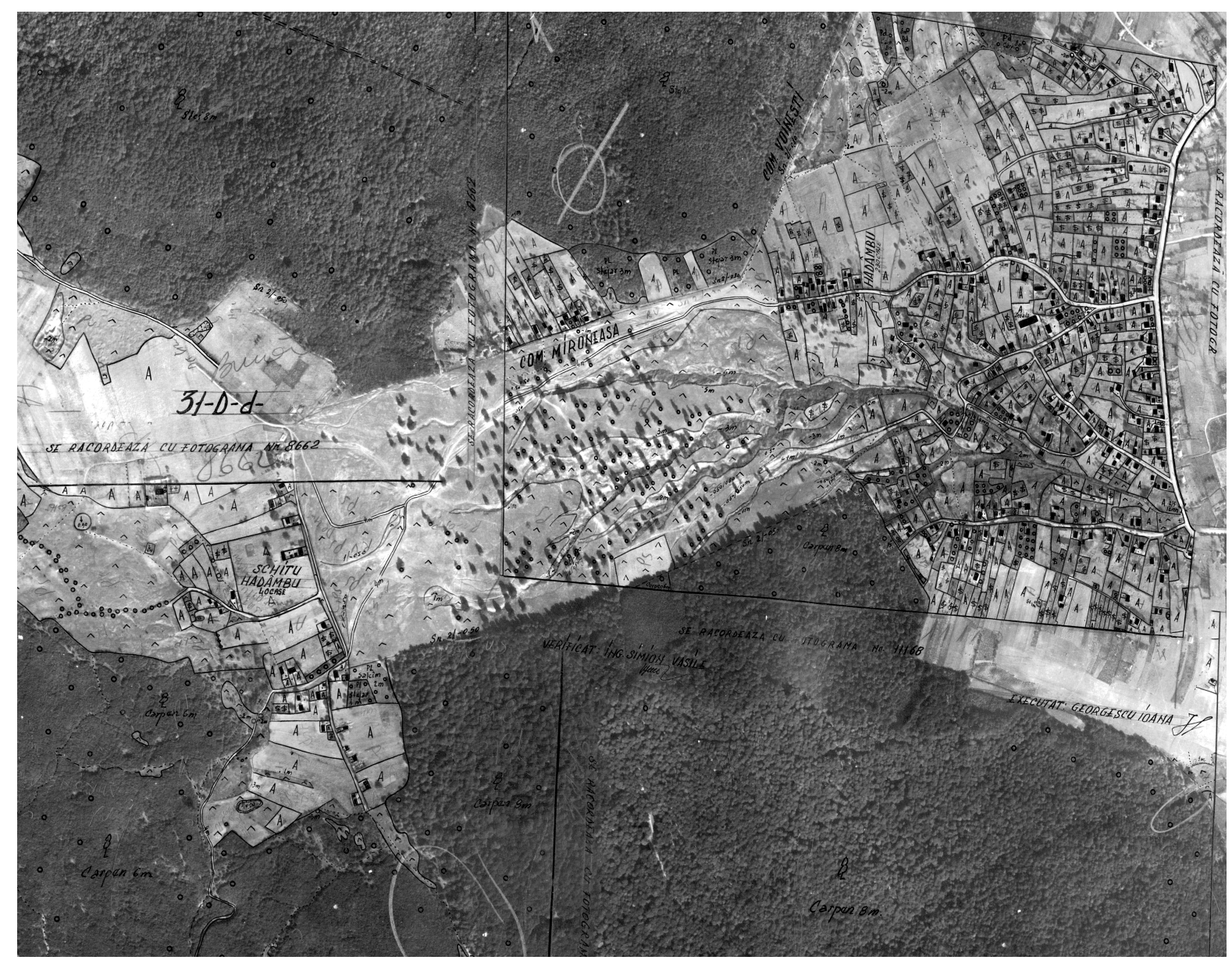

Fig. 3. Aerial image of the slope between Hadâmbu village and Hadâmbu Monastery (1971).

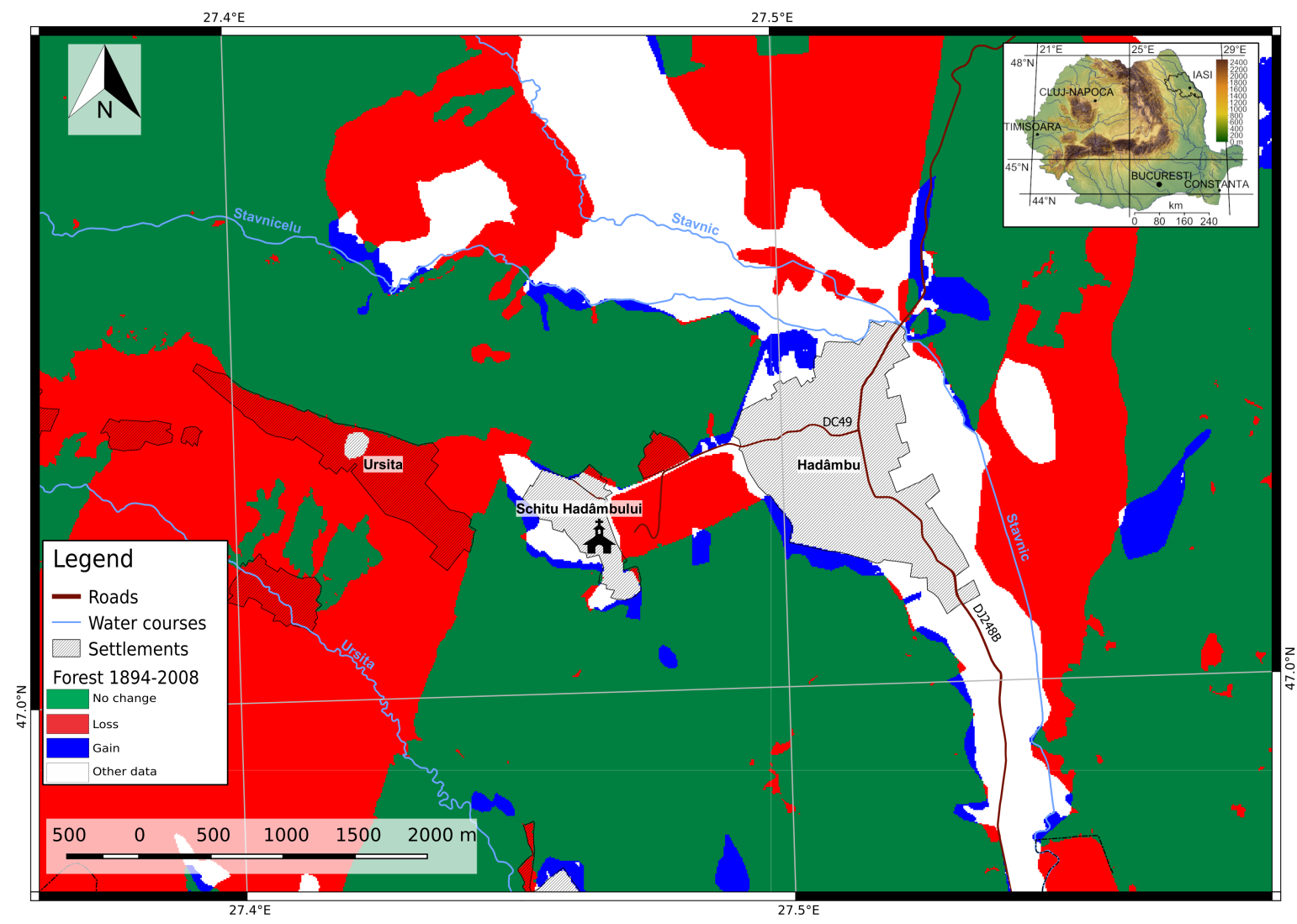

Fig. 4. Forest evolution around Hadâmbu village according to topographic sources (Moldavian Atlas 1:50 000 - 1890, Army Plans 1:20 000 - 1920, Ist and IInd ed. of 1:25 000 topographic maps - 1960 and 1984, aerial imagery - 2008). 